Brit. J. vener. Dis. (1965), 41, 286.

\title{
MEDICAL SOCIETY FOR THE STUDY OF VENEREAL DISEASES
}

\author{
SPRING MEETING IN AMSTERDAM
}

May 27 to 29, 1965

The spring meeting was attended by 74 members and their wives and included representatives from France, Denmark, Germany, Holland, and the United States of America. We were fortunate in having with us Dr William Brown, the director of the Venereal Diseases Branch of the Communicable Diseases Center in Atlanta, Georgia. The meeting was a combined one with the Dutch Society for Dermatology and a great deal of help in the organization was given by Dr Simons, the secretary of the Dutch Society. A ladies' programme had been organized by a committee headed by Mrs A. Prakken and our Dutch hosts were extremely generous in the hospitality which they offered to us.

The majority of the members arrived in Amsterdam in time for a luncheon party, held on the top storey of the Havengebouw, a sky-scraper building with a superb view over the town, the harbour, and the Rhine canal. An excellent menu had been prepared and the standard of gastronomy was in keeping with the magnificence of the outlook from the restaurant. In the afternoon a boat-trip through the canals of Amsterdam was filmed by members of the "Panorama" television team, who had come over specially from London to record some aspects of the meeting. The weather had generally been overcast but the sun obligingly came out during the boat-trip, which ended at the Rijksmuseum where guides were waiting to take the party to see the famous Rembrandt and Vermeer pictures. In the evening a cocktail party and reception at the Doelen Hotel was attended by both the British and the Dutch members.

On Saturday morning a demonstration of patients with a variety of dermatological conditions was held at the Binnengasthuis. About thirty patients were demonstrated and many excellent histological preparations were available for microscopical examination. Later in the morning the party moved to the New Congress Buildings at the Rai Centre, when the patients who had been presented earlier in the morning were discussed and some short papers were read. Luncheon in the Dutch style was served in the Congress Building. During the afternoon further short papers on dermatological and venereological subjects were read and a lively discussion took place; some of the papers are published in the present issue. The meetings were ably chaired by Prof. Vermeer and Dr C. S. Nicol and the programme finished almost at the appointed time.

During the morning the ladies had been taken on an excursion in the region of Amsterdam, visited the Franz Hals Museum at Haarlem, and lunched together with their Dutch hostesses.

On Saturday evening a dinner at the Hilton Hotel was attended by about 130 persons and a student gipsy band provided excellent music. The President, Dr C. S. Nicol, reviewed the activities of the Society over the past few years and pointed out that spring meetings abroad had now become a part of the regular pattern of its activities. He expressed the wish that these should continue at regular intervals, probably on alternate years. Prof. Vermeer replied for the Dutch Dermatological Society and made many gracious remarks about British medicine and British influence in Holland. Dr Fluker proposed the health of the guests and when the dinner ended most of the members continued the celebrations well into the night.

On Sunday morning an expedition by bus took members to a seaside resort at Zandvoort, but unfortunately the sky was overcast, the wind from the north, and the day quite unsuitable for sea or sun-bathing. Most members flew home on Sunday afternoon. The Society found Amsterdam a friendly and sympathetic city; many new friendships were made with Dutch colleagues and the variety of papers read at the scientific meeting demonstrated the wide interest in venereology at the present time. The presence of the "Panorama" B.B.C. television team and the programme shown on B.B.C. television the following Monday gave considerable national publicity to the activities of the Medical Society for the Study of Venereal Diseases and, once again, presented to the public the facts about the increasing incidence of the sexually-transmitted diseases.

R.D.C. 